[10] G.E.P. Box and K.B. Wilson, J. R. Statist. Soc. Ser. B, 13 (1951) 1.

[11] G.E. P Box, W.G. Hunter and J.S. Hunter, Statistics for Experimenters, Wiley, Chichester, 1978.

[12] E. Foster and R.V. Bathe, Chemom. Intell. Lab. Syst., 9 (1990) 207.

[13] G.E.P. Box and D.W. Behnken, Technometrics, 2 (1960) 445.

[14] P.W. Araujo, K. Kavianpour and R.G. Brereton, Analyst, 120 (1995) 295.

[15] C. Altesor, P. Corbi, I. Dol and M. Knochen, Analyst, 118 (1993) 1549.

[16] S.N. Deming and S.L. Morgan, Experimental Design: A Chemometric Approach, Elsevier, Amsterdam, 1987.

[17] N.R. Draper, Technometrics, 4 (1962) 219.
[18] R. Carlson, Å. Nilsson and M. Strömqvist, Acta Chem. Scand. Ser. B, 37 (1983) 7.

[19] D.H. Doehlert, Appl. Statit., 19 (1970) 231.

[20] Z. Benzo, P. Araujo, A. Sierraalta and F. Ruette, Anal. Chem., 65 (1993) 1107.

[21] H. Scheffé, J. R. Statist. Soc. Ser. B, 2 (1958) 344.

[22] H. Scheffé, J. R. Statist. Soc. Ser. B, 2 (1963) 235.

[23] J.L. Glajch, J.J. Kirkland and L.R. Snyder, J. Chromatogr., 238 (1982) 269.

Pedro W. Araujo and Richard G. Brereton are at the School of Chemistry, University of Bristol, Cantock's Close, Bristol BS8 1TS, UK. For bibliographical details see Part I of this article.

\title{
Thermally assisted hydrolysis and alkylation as a novel pyrolytic approach for the structural characterization of natural biopolymers and geomacromolecules
}

\author{
J.C. del Rio *, F. Martin, \\ F.J. Gonzalez-Vila \\ Seville, Spain
}

The high-temperature reaction of macromolecules with tetra-alkylammonium hydroxides has significantly improved the use of the conventional pyrolytic procedures which are widely used for the structural characterization of natural biopolymers and geomacromolecules. This new pyrolytic approach has overcome some of the analytical limitations of conventional pyrolysis allowing the detection of polar compounds as their alkyl derivatives. We report recent developments of the high-temperature hydrolysis and alkylation procedure, carried out in the presence of tetra-alkylammonium hydroxides, for the structural characterization of natural biopolymers and geomacromolecules such as lignins, humic substances, coals, asphaltenes and kerogens.

\section{Introduction}

Analytical pyrolysis coupled with mass spectrometry (Py-MS) or gas chromatography-mass spectrometry (Py-GC-MS) is now recognized as a powerful analytical technique for the chemical structural characterization of natural biopolymers and geomacromolecules [1-8]. The polymeric material undergoes heat-induced bond dissociation to give lower-molecular-mass compounds which reflect the composition of the original polymer. Analytical pyrolysis has many well known advantages.

- In many instances it is very reproducible and the results can be interpreted both qualitatively and quantitatively.

- No chemical pre-treatments and/or fractionations are necessary, thus avoiding possible contamination from laboratory manipulations.

- Predominantly primary pyrolysis products are obtained.

\footnotetext{
* Corresponding author.
} 
The ideal pyrolysis process should take place under open system conditions which allow immediate removal of the dissociation products from the hot zone to avoid the formation of numerous secondary products.

The results of $\mathrm{Py}-\mathrm{GC}-\mathrm{MS}$ have tremendously improved our knowledge of the chemical structure of natural macromolecules at the molecular level. However, it must be realized that some significant structural moieties can be heavily modified by unwanted thermal reactions which may lead to incorrect conclusions on the structure of the original polymer. Thus, Tegelaar et al. [9] noted that an esterified $p$-coumaric acid generates $p$-coumaric acid as its primary pyrolysis product that subsequently undergoes decarboxylation, giving rise to the formation of $p$-vinylphenol. Likewise, Martin et al. [10] observed decarboxylation of benzenecarboxylic acid standards upon conventional pyrolysis. Also, it has been demonstrated that long-chain alkylbenzenes and alkylnaphthalenes can result from secondary thermal reactions of aliphatic precursors [11,12]. On the other hand, analytical pyrolysis of polymers may also yield highly polar products such as carboxylic acids which are difficult to transfer from the pyrolyser and are almost impossible to chromatograph directly by GC. Therefore, pyrolysis may underestimate units bearing polar groups among the structural 'building blocks' of certain polymers.

Recently, flash heating in the presence of tetramethylammonium hydroxide (TMAH), the socalled pyrolysis-methylation, has been developed to improve the results gained by conventional pyrolysis $[10,11,13-16]$. This procedure avoids decarboxylation and produces methyl esters of carboxylic acids and methyl ethers of hydroxyl compounds. It has been demonstrated with standards of aliphatic esters and benzenecarboxylic acids that this procedure consists of a thermally assisted chemolysis rather than a true pyrolysis followed by 'in situ' methylation of the products [10,15-17]. The tetra-alkylammonium hydroxides react at high temperature with carboxyl, hydroxyl and ester groups to give the respective alkyl derivatives which are more amenable to gas chromatography. This technique has been used routinely in the direct analysis of solutions of fatty acids and triglycerides $[18,19]$. Dworzansky et al. $[20,21]$ used the 'pyrolytic methylation' for the generation of the chemotaxonomically characteristic profile of fatty acid methyl esters from different bacterial cells. More recently, this procedure has been applied to the structural characterization of a variety of natural and artificial polymers such as cutins, lignins, alkyd resins, polyester fibres, humic substances and kerogens $[10,13-17,22-34]$.

As Challinor stated [22], this technique has the advantages compared to chemical degradation and conventional pyrolysis that more structural information can be obtained about the polar components of some polymers, minimal sample manipulation is required, and the method is therefore more cost effective. However, studies of humic substances have very recently suggested the possibility that small amounts of benzenecarboxylic acid methyl esters could be produced from unoxidized lignin moieties by oxidation with the TMAH reagent when elevated temperatures and large contact times are used [35].

A limitation of the flash heating in the presence of TMAH is the inability to distinguish between any methoxy groups originally present in a molecule and those free hydroxyl groups that become methylated after pyrolysis in the presence of TMAH. To solve this problem, experiments with tetrabutylammonium hydroxyde (TBAH) have also been applied successfully to a variety of standards, biopolymers and geomacromolecules [27,32]. Pyrolysis in the presence of TBAH will introduce a butyl moiety into the original free hydroxyl group (forming an O-butyl ether) that can thus be distinguished from an original methoxyl function.

We report here recent developments in the pyrolysis in the presence of tetra-alkylammonium hydroxides for the structural characterization of a set of natural biopolymers and geomacromolecules including lignins, humic substances of various origins, coals, and asphaltenes and kerogens isolated from oil shales.

\section{Mechanism of thermally assisted hydrolysis and alkylation}

Flash heating in the presence of TMAH has been termed simultaneous pyrolysis methylation by some authors to distinguish it from pyrolytic methylation which has been used to derivatize free fatty acids and triglycerides in the injection port of the gas chromatograph $[18,19]$. This term has led to a misunderstanding of the mechanism. It has been demonstrated by several authors that the procedure consists of a thermally assisted chemolysis rather than pyrolysis followed by the methylation of the 
Table 1

Pyrolytic behaviour of some standard compounds

\begin{tabular}{|c|c|c|c|}
\hline Compound & Conventional Pyrolysis & Pyrolysis-methylation & Pyrolysis-butylation \\
\hline 1,2-Benzenedicarboxylic acid & 1,3-Benzofurandione & $\begin{array}{l}\text { 1,2-Benzenedicarboxylic acid, } \\
\text { dimethyl ester }\end{array}$ & $\begin{array}{l}\text { 1,2-Benzenedicarboxylic acid, } \\
\text { dibutyl ester }\end{array}$ \\
\hline 1,3-Benzenedicarboxylic acid & Benzoic acid & $\begin{array}{l}\text { 1,3-Benzenedicarboxylic acid, } \\
\text { dimethyl ester }\end{array}$ & $\begin{array}{l}\text { 1,3-Benzenedicarboxylic acid, } \\
\text { dibutyl ester }\end{array}$ \\
\hline 1,4-Benzenedicarboxylic acid & Benzoic acid & $\begin{array}{l}\text { 1,4-Benzenedicarboxylic acid, } \\
\text { dimethyl ester }\end{array}$ & $\begin{array}{l}\text { 1,4-Benzenedicarboxylic acid, } \\
\text { dibutyl ester }\end{array}$ \\
\hline $\begin{array}{l}\text { 1,2,4-Benzenetricarboxylic } \\
\text { acid }\end{array}$ & $\begin{array}{l}\text { Benzoic acid }+1,3 \\
\text { benzofurandione }\end{array}$ & $\begin{array}{l}1,2,4,- \text { Benzenetricarboxylic, } \\
\text { trimethyl ester }\end{array}$ & $\begin{array}{l}\text { 1,2,4,-Benzenetricarboxylic acid, } \\
\text { tributyl ester }\end{array}$ \\
\hline $\begin{array}{l}\text { 1,3,5-Benzenetricarboxylic } \\
\text { acid }\end{array}$ & Benzoic acid & $\begin{array}{l}\text { 1,3,5-Benzenetricarboxylic } \\
\text { acid, trimethyl ester }\end{array}$ & $\begin{array}{l}\text { 1,3,5-Benzenetricarboxylic acid, } \\
\text { tributyl ester }\end{array}$ \\
\hline $\begin{array}{l}\text { 2-Propenoic acid,3-(4- } \\
\text { hydroxyphenyl) }\end{array}$ & 4-Vinylphenol & $\begin{array}{l}\text { 2-Propenoic acid,3-(4- } \\
\text { methoxyphenyl), methyl ester }\end{array}$ & $\begin{array}{l}\text { 2-Propenoic acid,3-(4- } \\
\text { butoxyphenyl), butyl ester }+4- \\
\text { vinylbutoxybenzene }(1: 1)\end{array}$ \\
\hline $\begin{array}{l}\text { 2-Propenoic acid,3-(3- } \\
\text { methoxy-4-hydroxyphenyl) }\end{array}$ & 4-Vinyl-2-methoxyphenol & $\begin{array}{l}\text { 2-Propenoic acid,3(3,4- } \\
\text { dimethoxyphenyl), methyl } \\
\text { ester }\end{array}$ & $\begin{array}{l}\text { 2-Propenoic acid,3-(3-methoxy-4- } \\
\text { butoxyphenyl), butyl ester + 4- } \\
\text { vinyl-2-methoxybutoxybenzene } \\
(1: 5)\end{array}$ \\
\hline $\begin{array}{l}\text { 2-Propenoic acid,3-(3,5- } \\
\text { dimethoxy-4-hydroxyphenyl) }\end{array}$ & $\begin{array}{l}\text { 4-Vinyl-2,6-dimethoxy- } \\
\text { phenol }\end{array}$ & $\begin{array}{l}\text { 2-Propenoic acid,3-(3,4,5- } \\
\text { trimethoxyphenyl), methyl } \\
\text { ester }\end{array}$ & $\begin{array}{l}\text { 2-Propenoic acid,3-(3,5- } \\
\text { dimethoxy-4-butoxyphenyl), butyl } \\
\text { ester + 4-vinyl-2,6- } \\
\text { dimethoxybutoxybenzene (1:10) }\end{array}$ \\
\hline $\begin{array}{l}\text { 2-Propenol,3-(4- } \\
\text { hydroxyphenyl) }\end{array}$ & $\begin{array}{l}\text { 2-Propenol,3-(4- } \\
\text { hydroxyphenyl) }\end{array}$ & $\begin{array}{l}\text { 2-Propenol,3-(4- } \\
\text { methoxyphenyl), methyl ether }\end{array}$ & 2-Propenol,3-(4-butoxyphenyl) \\
\hline $\begin{array}{l}\text { 2-Propenol,3-(3-methoxy-4- } \\
\text { hydroxyphenyl) }\end{array}$ & $\begin{array}{l}\text { 2-Propenol,3-(3-methoxy- } \\
\text { 4-hydroxyphenyl) }\end{array}$ & $\begin{array}{l}\text { 2-Propenol,3-(3,4 } \\
\text {-dimethoxyphenyl }) \text {, methyl } \\
\text { ether }\end{array}$ & $\begin{array}{l}\text { 2-Propenol,3-(3-methoxy-4- } \\
\text { butoxyphenyl) }\end{array}$ \\
\hline $\begin{array}{l}\text { 2-Propenol,3-(3,5-dimethoxy- } \\
\text { 4-hydroxyphenyl) }\end{array}$ & $\begin{array}{l}\text { 2-Propenol,3-(3,5- } \\
\text { dimethoxy- } \\
\text { 4-hydroxyphenyl) }\end{array}$ & $\begin{array}{l}\text { 2-Propenol,3-(3,4,5- } \\
\text { trimethoxyphenyl), methyl } \\
\text { ether }\end{array}$ & $\begin{array}{l}\text { 2-Propenol,3-(3,5-dimethoxy-4- } \\
\text { butoxyphenyl) }\end{array}$ \\
\hline
\end{tabular}

released pyrolysis products $[10,15-17,22,23]$. The procedure has therefore recently been termed more appropriately thermally assisted hydrolysis and methylation (THM) [16], although the term pyrolysis-methylation seems to be more popular among authors. The terms THM, and the corresponding thermally assisted hydrolysis and butylation (THB) for pyrolysis in the presence of TBAH, will be used in this text.

There are few reasons to assume that a reaction between a macromolecule and the tetra-alkylammonium hydroxide occurs at high temperatures which would release the structural units. In fact, the reported findings are generally very different from the results obtained by direct methylation followed by flash pyrolysis $[36,37]$.

Pyrolysis of a set of benzenecarboxylic acids, cinnamic acids and cinnamyl alcohols was performed in order to assess their behaviour upon conventional pyrolysis and flash heating in the presence of tetra-alkylammonium hydroxides. Table 1 shows the pyrolysis products obtained by the different procedures.
It can be observed that the benzenedicarboxylic and benzenetricarboxylic acids undergo decarboxylation and produce predominantly benzoic acid upon conventional pyrolysis. Only in the case where two carboxylic groups are located in ortho positions is the corresponding anhydride (1,3-isobenzofurandione) formed. Likewise, cinnamic acids undergo decarboxylation upon conventional pyrolysis, yielding the respective vinylphenols. These experiments clearly demonstrate the limitations of the conventional pyrolysis technique for the structural characterization of macromolecules based on benzenecarboxylic acid moieties, since these decarboxylate and are therefore not released intact upon pyrolysis.

However, pyrolysis in the presence of TMAH and TBAH releases the benzenecarboxylic acids and cinnamic acids as their methyl and butyl esters, respectively. The absence of methyl benzoate and 1,3-isobenzofurandione in this case reinforces the view that a high-temperature hydrolysis and alkylation mechanism takes place rather than a methylation of the pyrolysis products, as postulated by 


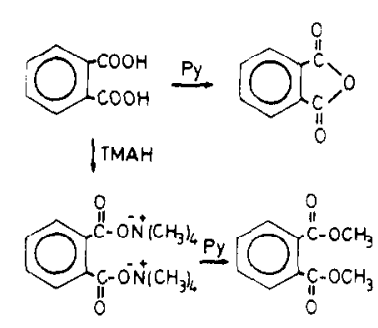

(a)

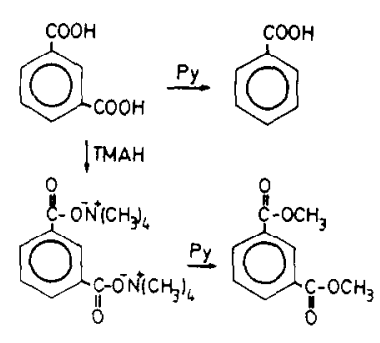

(b)

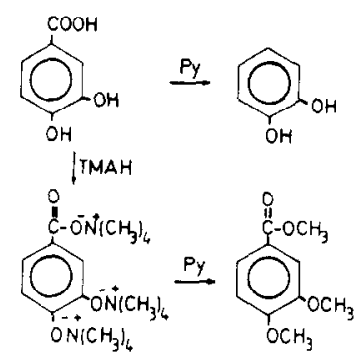

(c)

Fig. 1. Mechanism of the pyrolysis of the benzenecarboxylic acids in the absence and in the presence of TMAH.

various authors $[10,14-17,23,28]$. In the case of the cinnamic acids, pyrolysis in the presence of TBAH also releases the by-products arising from the decarboxylation. These by-products are more predominant in substituted cinnamic acids of
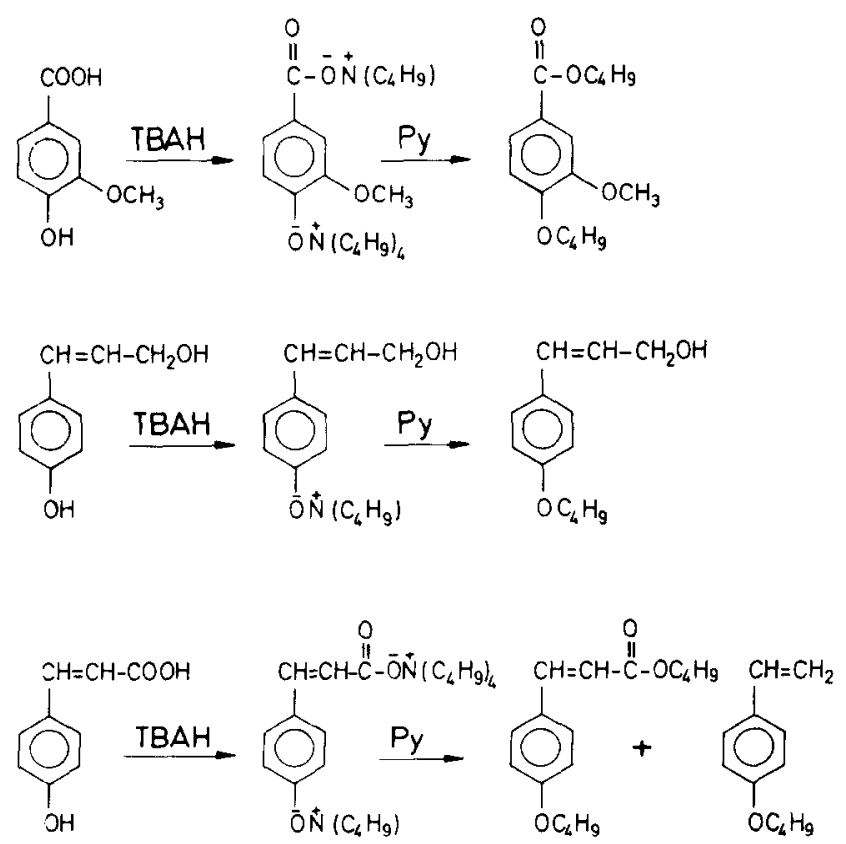

Fig. 2. Suggested mechanism for the pyrolysis in the presence of TBAH of different aromatic acid standards. higher molecular weight. In the case of the cinnamyl alcohols they are released as such upon conventional pyrolysis (i.e., by volatilization) and as dimethyl ethers upon THM. After THB, only the phenolic $\mathrm{OH}$ become butylated while the aliphatic alcohols remain unsubstituted, probably as a result of their weakly acidic character. Attempts to butylate the aliphatic alcohol groups failed at three different pyrolysis temperatures $(300,500$ and $700^{\circ} \mathrm{C}$ ). According to all these data we suggest the mechanism shown in Fig. 1 for the pyrolysismethylation of substituted benzenecarboxylic acids. Likewise, Fig. 2 shows the mechanisms of pyrolysis-butylation of several lignin-derived units.

With respect to the quantitative aspects of THM, only few data have been published up to date and mainly refer to humic substances. Thus, it has been shown that the relative abundance of products released from humic substances upon THM is about fifteen times higher than in conventional pyrolysis [11]. Other authors also confirmed that THM produces product yields two to four times higher than the conventional pyrolysis of humic substances [30]. It has also been reported that the relative amounts of products released after conventional pyrolysis and THM were different, depending on the nature of the samples analyzed. For example, in aquatic fulvic acids (FA), THM increased the amounts of fatty acids tenfold whereas for terrestrial FA, the fatty acids increase 1.4-fold [34].

\subsection{Flash heating of natural biopolymers in the presence of tetra-alkylammonium hydroxides}

As mentioned above, pyrolysis in the presence of TMAH has long been used for the direct analysis of naturally occurring fatty acids, triglycerides and waxes $[13-15,18,19]$. Triglycerides and waxes are hydrolysed and converted into their respective fatty acid methyl esters via intermediate tetramethylammonium hydroxide salts. Dworzansky et al. [20,21] used the 'pyrolytic methylation' for the generation of the chemotaxonomically characteristic profile of fatty acid methyl esters from different bacterial cells. The method avoids the laborious and time-consuming sample preparation of extractive methods. Holzer et al., [38] used a related quaternary amine, trimethylanilinium hydroxide to obtain the fatty acid profile of bacterial cells. Most of the products released corresponded to a hydrolysis reaction followed by quantitative methylation 
of the fatty acid moieties and partial methylation of the aliphatic hydroxyl groups.

THM of proteinaceous fibres, such as silk and wool, has also been attempted [14]. The methyl derivatives of phenol and $o$-cresol were identified in the products of silk, which could arise from the hydrolysis and methylation of tyrosine, present in fibroin (silk) in high abundance. The THM of polysaccharides has also been performed. Martin and co-workers studied the compounds released after the pyrolysis-methylation of the extracellular polysaccharide produced by the lignilytic fungi Pleurotus eryngii [39]. The permethylated monoand disaccharides were the main compounds released. Although there is no published report on the behaviour of pure polysaccharides, several permethylated compounds arising from cellulosic moieties in humic substances have been released upon THM [10,24].

In the case of lignins, conventional pyrolysis has long been used for the identification of their different structural units $[3,40-43]$ and has also been found suitable for following the lignin signature in the environment $[4,8,44,45]$. However, as previously discussed, conventional flash-pyrolysis underestimates the potential presence of units bearing carboxyl groups among the lignin structural 'building blocks'. Few papers have been devoted to the use of THM for the structural characterization of lignins. Mulder et al. [33] presented preliminary data for the pyrolysis of bamboo milled wood lignin (MWL) and more recently, Martin et al. [27] and Clifford et al., [17] have conducted systematic studies of THM of the lignins isolated from different vascular plants. Challinor has recently published work on the derivatization of heartwood of a number of species [46].

Several MWLs, corresponding to the three different structural groups (grass, gymnosperms and angiosperms), have been subjected to THM. Fig. 3 shows the chromatogram of the compounds released from the Pine MWL after THM. The pyrolysis of the lignins in the presence of TMAH releases the methyl esters and methyl ethers of the various lignin monomers. It is interesting to note the release of several phenolic compounds bearing carboxyl groups (appearing as methyl esters), whose structures are indicated on the corresponding chromatographic peaks. These compounds have not been detected previously by conventional pyrolysis as being part of the lignin structure. Different types of carboxylic units, such as benzenecarboxylic acids, benzeneacetic acids, ben-

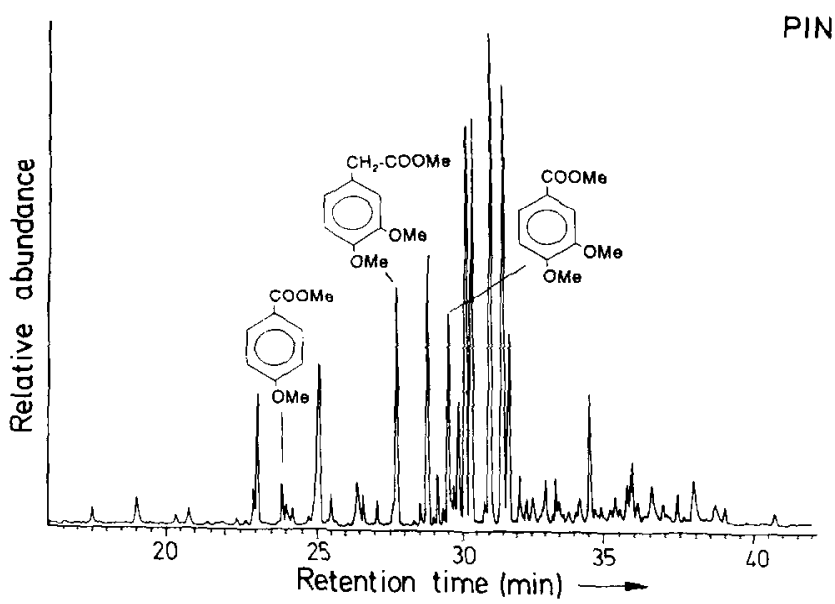

Fig. 3. Total ion chromatogram of the compounds released after THM of pine milled wood lignin. Pyrolysis temperature $500^{\circ} \mathrm{C}$. Chromatographic conditions are: fused-silica capillary column (FFAP) of $30 \mathrm{~m}$ length and $0.2 \mathrm{~mm} \mathrm{I.D.;} \mathrm{injector} \mathrm{at} 250^{\circ} \mathrm{C}$, detector (FID) at $300^{\circ} \mathrm{C}$ and oven temperature from $40^{\circ} \mathrm{C}$ to $250^{\circ} \mathrm{C}$ at $6^{\circ} \mathrm{C} / \mathrm{min}$. Only the structures of the aromatic acids are shown in the chromatograms.

zenepropanoic acids and benzenepropenoic acids (cinnamic acids), were released from the MWL studied. Trimethoxypropane derivatives were also released [ 17,27], which is indicative of hydrolysis and subsequent methylation. Flash heating in the presence of TMAH at sub-pyrolysis temperatures $\left(310^{\circ} \mathrm{C}\right)$ produced similar chromatograms, also suggesting that the method probably involves mainly chemolytic reactions [17].

THM has also been applied succesfully in monitoring the structural changes that lignin undergoes during the coalification process [28]. However, THM has a significant drawback for structural studies of degraded lignins which might have suffered demethylation, as occurs during coalification $[4,45]$. Since degraded lignins may contain both methoxy and free hydroxyl groups which will become methylated upon THM, these last cannot be distinguished from the methoxy groups originally present in the lignin macromolecule. To avoid this problem, Martin et al. [27] and del Rio et al. [32] introduced pyrolysis in the presence of TBAH for differentiating between the free hydroxyl groups and the methoxyl groups originally present in the structure of degraded lignin.

\subsection{Flash heating of natural geomacromolecules in the presence of tetra-alkylammonium hydroxides}

This technique has also been proposed as an improved alternative for the structural study of nat- 


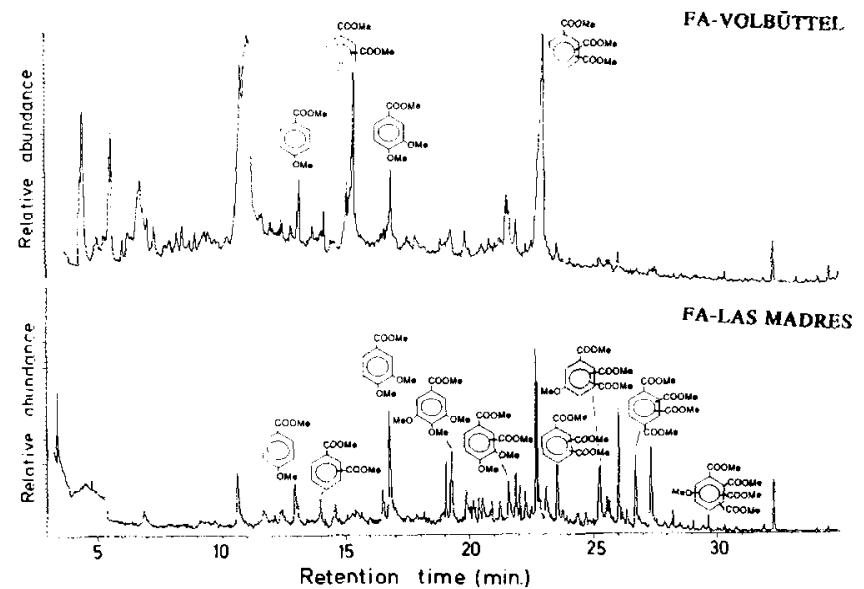

Fig. 4. THM of two fulvic acids: Vollbüttel (Germany), and water logged peatland (Las Madres, South Spain), isolated according to Martin et al. [10]. Pyrolysis temperature $700^{\circ} \mathrm{C}$. Chromatographic conditions are: fused-silica capillary column (SE-52) of $25 \mathrm{~m}$ lenght and $0.2 \mathrm{~mm} \mathrm{I.D.;} \mathrm{injector} \mathrm{at} 270^{\circ} \mathrm{C}$, detector (FID) at $300^{\circ} \mathrm{C}$ and oven temperature from $40^{\circ} \mathrm{C}$ to $270^{\circ} \mathrm{C}$ at $6^{\circ} \mathrm{C} / \mathrm{min}$. The structures of the aromatic acids are shown in the chromatograms.

ural geomacromolecules such as resins, resinites, humic substances (humic acids, fulvic acids, humins), coals, asphaltenes and kerogens [10,18,23-26,28-31,34].

Natural resins and resinites based on diterpenoid carboxylic acids and present in the geosphere have been analysed using THM [23,24]. Diterpenoid resin acids were smoothly and quantitatively methylated after pyrolysis in the presence of TMAH, without significant thermal degradation, decarboxylation or isomerization of olefinic structures. However, some side reactions, which result in the incorporation of nitrogen from the methylating agent, have been reported for the resin acids which contain additional carbonyl and/or hydroxyl groups.

Fulvic acids (FA) and humic acids (HA) with different origins (aquatic and terrestrial) have been analysed by THM [ 10,25,26,29-31]. Fig. 4 shows the chromatograms of the products released after THM of two different FA. The flash heating of FA in the presence of TMAH yields mainly derivatives from polysaccharides and lignin moieties existing in the FA macromolecular structure. This procedure releases moieties that have not been observed previously upon conventional pyrolysis, because they were too polar or too reactive. The most striking feature was the identification of aromatic acids (structures shown on the corresponding chroma- tographic peaks), which were previously reported as being building blocks of the FA structure in models based upon oxidative degradations [47]. Saiz-Jimenez et al. [25] also found that large quantities of aromatic acids were released from soil and lake FA, suggesting that these compounds represent final steps in the oxidation of the side-chain during microbial degradation of lignins.

A similar situation to that above occurs in the case of HA. Fig. 5 shows the chromatograms of the compounds released after THM of two different HA. High proportions of long-chain fatty acids were released, with minor amounts of aromatic acids. Aliphatic series such as fatty acid methyl esters, $\alpha, \omega$-dicarboxylic acid dimethyl esters, $\omega$ methoxy-fatty acid methyl esters and triterpenoid compounds with ursane, oleanane and hopane skeletons, were also detected in HA. Other authors [29-31] also observed the release of high amounts of fatty acid methyl esters and aromatic acid methyl esters upon THM of different soil HAs, suggesting

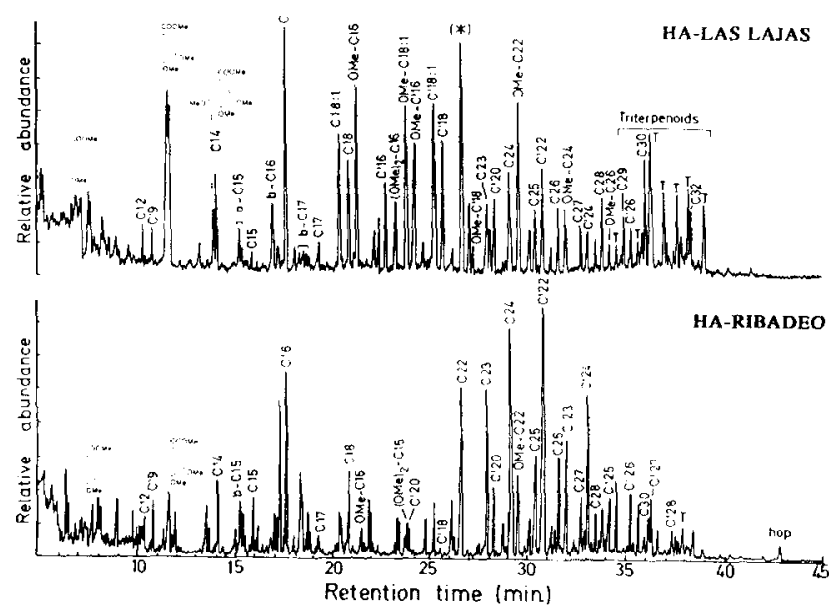

Fig. 5. THM of two humic acids from an Andosol (La Lajas, Canary Islands) and a Podsol (Ribadeo, north Spain), isolated according to Martin and GonzalezVila [36]. Pyrolysis temperature $500^{\circ} \mathrm{C}$. Chromatographic conditions are: fused-silica capillary column (DB-5) of $25 \mathrm{~m}$ length and $0.2 \mathrm{~mm}$ I.D.; injector at $300^{\circ} \mathrm{C}$, detector (FID) at $300^{\circ} \mathrm{C}$ and oven temperature from $40^{\circ} \mathrm{C}$ to $300^{\circ} \mathrm{C}$ at $6^{\circ} \mathrm{C} / \mathrm{min}$. Only the structures of the aromatic acids are shown in the chromatograms. $\mathrm{C} n=$ monocarboxylicacids, $\mathrm{C} n: 1=$ unsaturated monocarboxylic acids, $\mathrm{b}-\mathrm{C} n=$ branched monocarboxylic acids, $C^{\prime} n=$ dicarboxylic acids, $C^{\prime} n: 1=$ unsaturated dicarboxylic acids, $\mathrm{OMe}-\mathrm{C} n=$ methoxy-monocarboxylic acids, $(\mathrm{OMe})_{2}-\mathrm{C} n=$ dimethoxy-monocarboxylic acids, $\quad$ OMe-C' $n=$ methoxy-dicarboxylic acids, $\mathrm{T}=$ triterpenoid acids. 
that these are structural components of the humic macromolecule. In general, the data demonstrated that this technique provides relatively good preservation of the original carboxyl and hydroxyl groups in lignin phenols owing to protection of the functional groups from thermal reactions. Taking into account of all these data, we agree with other authors $[11,30]$ in that the present structural models for humic substances, based largely on conventional pyrolysis studies [48], should be re-evaluated. In this last paper, the network structure of $\mathrm{HA}$ is given as being devoid of oxygen constituents, largely because no oxygen-containing compounds were reported among pyrolysis compounds [48], although the elemental analyses indicated the presence of $33-34 \%$ of oxygen in the HA investigated. The same authors have now revised their original network structure, with the inclusion of oxygen in the form of carboxyls, phenolic and alcoholic hydroxyls, carboxyl esters and ethers [49].

The THM of the HA isolated from two peat and lignite deposits (Padul peat, south Spain; Pontes lignite, north Spain) have also been accomplished recently [28]. They released a great variety of components, the lignin-derived monomers being the most prominent. Again, a very striking feature was the release of benzenecarboxylic acid moieties which have not been observed previously by conventional pyrolytic techniques. These benzenecarboxylic acid moieties were released in higher amounts from the lignite HA. This suggests that the content of carboxylic groups increases with coalification, at least up to the lignite stage, although a wider set of samples of different rank is needed to infer coalification trends. Oxidation of the C-3 side chain of the lignin structure would produce the benzenecarboxylic acids and the benzylic ketones which were identified. The presence of carbonyl and carboxyl groups located at the $\alpha$ carbon of lignin monomeric units was previously presupposed in the structural model for low-rank coals proposed by Hatcher [50]. Several other compounds with the carboxyl group located at the $\beta$ - and $\gamma$-carbons, such as benzeneacetic acids and benzenepropionic acids respectively, were also identified among the pyrolysis products. The benzenepropionic acids were mainly released from the peat $\mathrm{HA}$, and in very low amounts from the lignite $\mathrm{HA}$, indicating that they might be produced in the early stage of the coalification process but are subsequently oxidized and disappear with increasing coalification. The benzeneacetic acids, in contrast,

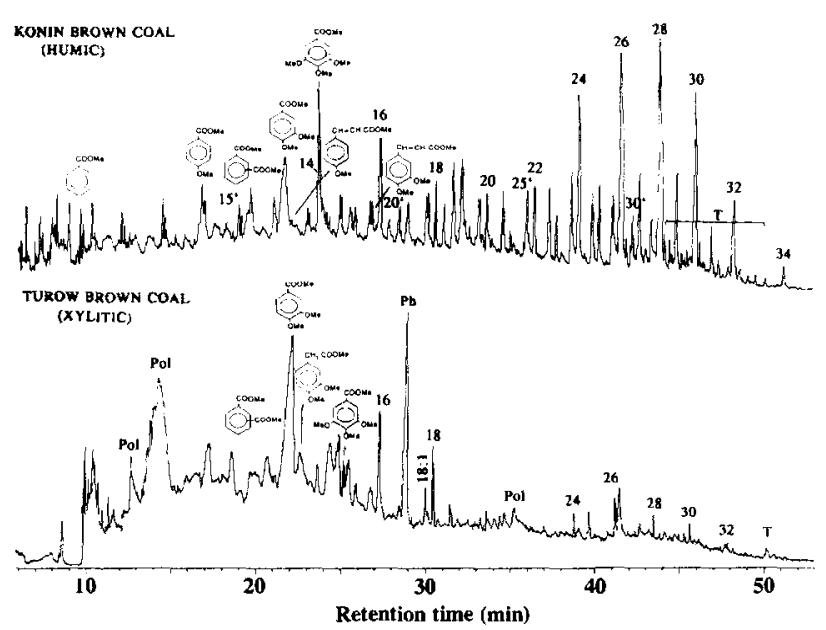

Fig. 6. THM of two different brown coals, Turow (xylitic) and Konin (humic), from Poland. Chromatographic conditions are: fused silica capillary column (SE-52) of $25 \mathrm{~m}$ length and $0.2 \mathrm{~mm}$ I.D.; injector at $300^{\circ} \mathrm{C}$, detector (FID) at $300^{\circ} \mathrm{C}$ and oven temperature from $40^{\circ} \mathrm{C}$ to $300^{\circ} \mathrm{C}$ at $6^{\circ} \mathrm{C} / \mathrm{min}$. $n=$ chain length of fatty acid methyl esters; $n^{\prime}=$ chain length of $n$-alkane/ $n$-alkene pairs; Pol=polysaccharide-derived compounds.

are not present in the peat HA but appear in the lignite $\mathrm{HA}$, which might suggest their formation at this later stage.

However, a well-documented consequence of the coalification process, is the demethylation of methoxy groups in the guaiacyl and syringyl units of the lignin macromolecule and the formation of the corresponding catechols $[4,45]$, can be highly biased during THM. Since this technique produces the methyl ethers of the free phenolic groups, these cannot be differentiated from the original methoxy groups in the lignin macromolecule. Pyrolysis in the presence of TBAH of the HAs of the Padul peat and Pontes lignite has been used to avoid this inconvenience [32]. The butyl aryl ethers present in the lignin moieties arise from both free phenolic groups which become butylated, and by TBAHassisted cleavage of the alkyl aryl ether bonds which leads to the formation of a butyl aryl ether. Moieties with guaiacyl and syringyl structures, having the $\mathrm{OH}$ groups at $\mathrm{C}-3$ and $\mathrm{C}-5$ either methylated or butylated, were identified in both samples. The demethylation of the lignin moieties during coalification was inferred from the release of larger amounts of moieties with the $\mathrm{OH}$ groups at C-3 and $\mathrm{C}-5$ butylated from the lignite than from the peat.

Flash heating of whole coals in the presence of TMAH has also been performed. Fig. 6 shows the 
compounds released after THM of two different coals from Poland (a xylitic and a humic brown coal). The data are similar to those obtained after THM of the HAs isolated from other low-rank coals, with the release of a range of benzenecarboxylic acid moieties and series of fatty acid methyl esters and hopanoic acid methyl esters not usually found upon conventional pyrolysis. Whereas the xylitic coal released predominantly lignin-derived aromatic units, with high amounts of aromatic acids, the humic coal released high amounts of fatty acids (as methyl esters) with minor amounts of aromatic acids. The long-chain fatty acids exhibit a very strong even-carbon-number predominance in the higher molecular weight region, which is thought to be indicative of the distribution of the monocarboxylic acids bound to the coal structure via ester linkages. Kralert et al. [51] also observed the release of series of fatty acids with strong evenover-odd predominance after THM of other lowrank coals.

Kerogens and asphaltenes isolated from the Puertollano (Central Spain) oil shales have also been analysed by THM. Challinor [14] has presented preliminary data for the use of THM in the characterization of the aliphatic ester moieties linked to the kerogen matrix of the Rundle shale. The main compounds released were series of alkane/alkene fatty acids, benzenecarboxylic acids, lignin-derived aromatic units and hopanoid compounds. The identification of long-chain fatty acids, benzenecarboxylic acids and hopanoic acids is noteworthy since they have not been released previously from kerogens and asphaltenes by conventional pyrolysis. The chemical structures of the released products indicate that considerable amounts of functionalized compounds are bound to the macromolecular structure via ester and ether linkages.

Fig. 7 shows the distribution of the fatty acids released from the kerogen and asphaltene fractions isolated from the Puertollano oil shale. The series of fatty acids were identified in the range from $\mathrm{C}_{8}$ up to $\mathrm{C}_{36}$, with a slight even-over-odd predominance and maxima at $\mathrm{C}_{16}$ and $\mathrm{C}_{18}$. A very striking feature was the release of small amounts of unsaturated $C_{18: 1}$ and $C_{16: 1}$ fatty acids. These unsaturated moieties may have been incorporated and preserved into the kerogen and asphaltene macromolecular network and have been released previously from the Puertollano kerogen by room temperature alkaline permanganate oxidation [52]. Barakat [53] also released different series of fatty acids
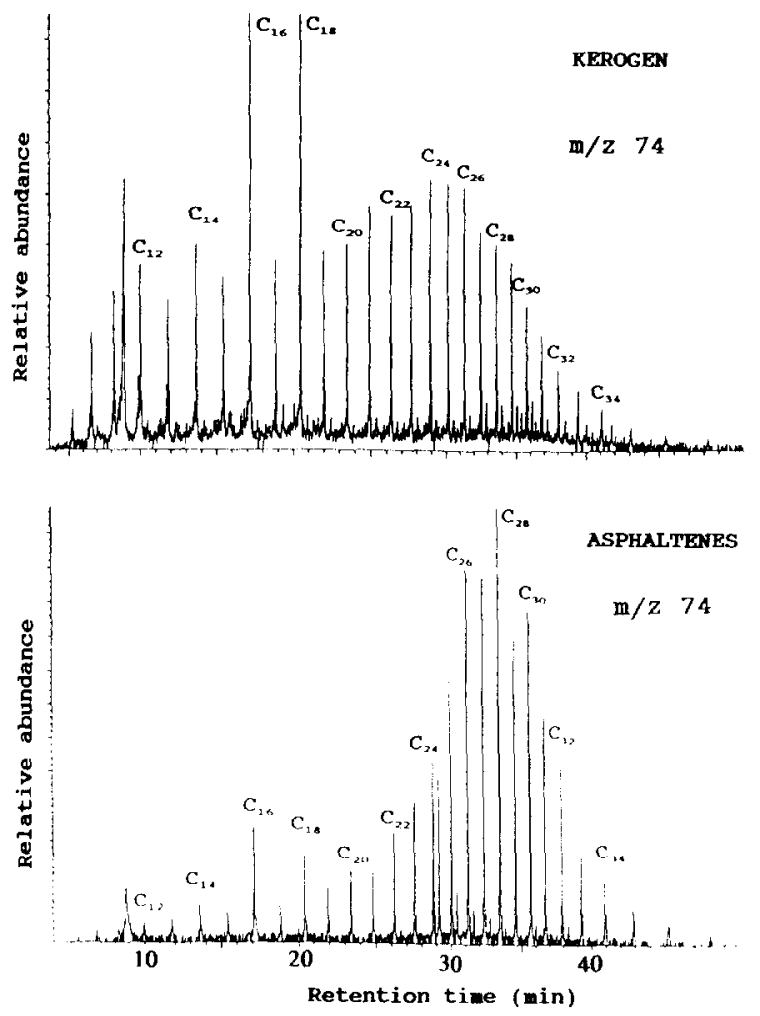

Fig. 7. Mass chromatogram of the ion $\mathrm{m} / \mathrm{z} 74$ showing the distribution of the fatty acids released from the kerogen and asphaltenes isolated from the Puertollano oil shale. Pyrolysis temperature $500^{\circ} \mathrm{C}$. Chromatographic conditions are: fused silica capillary column (SE-52) of $25 \mathrm{~m}$ length and $0.2 \mathrm{~mm}$ I.D.; injector at $300^{\circ} \mathrm{C}$, detector (FID) at $300^{\circ} \mathrm{C}$ and oven temperature from $40^{\circ} \mathrm{C}$ to $300^{\circ} \mathrm{C}$ at $6^{\circ} \mathrm{C} / \mathrm{min}$.

from Monterey kerogen with an even carbon number predominance, as well as unsaturated $C_{16: 1}$ and $\mathrm{C}_{18: 1}$, by alkaline hydrolysis. Series of 2-methoxy fatty acids, $\omega$-methoxy fatty acids and $\alpha, \omega$-dicarboxylic acids were also identified in all the samples, as their methyl esters, with strong even-over-odd predominance. All these series might derive from ester bound fatty acids protected in the most refractory part of the macromolecular network. Kawamura and Ishiwatari [54] defined the tightly bound carboxylic acids as those released only on pyrolysis. Tightly bound fatty acids are generally considered to originate from the incorporation of partly altered lipids into kerogens at an early stage of sedimentation [54-56]. Subsequently, such acids would be protected from diagenetic degradation and would be released only during laboratory heating experiments or during natural catagenic evolution [55]. Carboxylic acids tightly bound to kerogens can be inherited directly from living organisms. The fatty acids released on pyrolysis 
were linked to the macromolecular network via sterically protected, and hence, non-hydrolysable ester bonds. The even-carbon-number predominance of the kerogen-bound fatty acids and their distribution suggest that the fatty acids might arise from the biopolymers cutin and suberin.

Different aromatic acids were released after THM of asphaltenes and kerogens. Benzenecarboxylic acids (as methyl esters) and their methoxylated counterparts, such as the 3,4-dimethoxyand 3,4,5-trimethoxybenzenecarboxylic acids were the main aromatic acids released. Dimeric products of lignins were also generated after pyrolysis-methylation of kerogens and asphaltenes. These aromatic components might derive from higher plant lignins and possibly also from tannins and are always considered as indicators of a terrestrial origin. The presence of lignin-derived moieties has been shown previously in the Messel oil shale kerogen by the application of mild hydrogenation [57]. Hopanoid compounds were also released upon THM of the asphaltenes and kerogens. The main compounds released were hopanoic acids and hopenes. The fact that hopanoic acids are released from the geopolymeric matrix by THM indicated that they are bonded at their side-chain to the complex network of the kerogen and asphaltene, presumably through an ester linkage. Hopanoid compounds bound through ether bonds are released as hopenes since the alcohols do not become methylated. The identification of hopenes substantiates the previous suggestions that significant amounts of triterpenols are linked via ether bonds to the geopolymeric matrix.

\section{Concluding remarks}

The presence of polar moieties, mainly units bearing carboxyl groups, in the structures of some biopolymers and geomacromolecules has largely been underestimated as a result of the analytical limitations of conventional pyrolysis. Flash heating in the presence of tetra-alkylammonium hydroxides avoids decarboxylation and releases carboxylic groups in aliphatic and aromatic structures. This is therefore a promising and useful technique for the rapid analysis of natural macromolecules, giving valuable complementary information on their structures. Thus, the data provided by flash heating in the presence of tetra-alkylammonium hydroxides will make possible a re-evaluation of the structural models for some geomacromolecules such as humic substances, low-rank coals, or kerogens, which have been based largely on conventional pyrolysis studies. This analytical approach can thus also provide insights into the coalification process. In particular, the use of flash heating in the presence of TBAH avoids decarboxylation and at the same time allows differentiation between the free and methylated 3-O and 5-O groups in the altered lignin macromolecule, and thus the investigation of the demethylation and demethoxylation processes which occur during coalification.

\section{Acknowledgements}

The authors thank Dr. F. Czechowski for providing the coal samples from Poland. Mrs. T Verdejo is also acknowledged for her technical assistance.

\section{References}

[1] S.R. Larter and A.G. Douglas, J. Anal. Appl. Pyrolysis, 4 (1982) 1-19.

[2] F. Behar and R. Pelet, J. Anal. Appl. Pyrolysis, 8 (1985) 173-187.

[3] C. Saiz-Jimenez and J.W. de Leeuw, Org. Geochem., 10 (1986) 869-876.

[4] P.G. Hatcher, H.E. Lerch III, R.K. Kotra and T.V. Verheyen, Fuel, 67 (1988) 1069-1075.

[5] J.C. del Rio, J. Garcia-Molla, F.J. Gonzalez-Vila and F. Martin, J. Chromatogr. A, 657 (1993), 119-122.

[6] H.-R. Schulten, J. Anal. Appl. Pyrolysis, 25 (1993) 97-122.

[7] H.-R. Schulten, in N. Senesi and T.M. Miano (Editors), Humic Substances in the Global Environment and Implications in Human Health, Elsevier, Amsterdam, 1994, pp. 43-56.

[8] F.J. González-Vila, J.C. del Rio, G. Almendros and F. Martin, Fuel, 73 (1994) 215-221.

[9] E.W. Tegelaar, J.W. de Leeuw and P.J. Holloway, J. Anal. Appl. Pyrolysis, 15 (1989) 289-295.

[10] F. Martin, F.J. González-Vila, J.C. del Rio and T. Verdejo, J. Anal. Appl. Pyrolysis, 28 (1994) 7180.

[11] C. Saiz-Jimenez, Environ. Sci. Technol., 28 (1994) 1773-1780.

[12] C. Saiz-Jimenez, Org. Geochem., 23 (1995) 8185.

[13] J.M. Challinor, J. Anal. Appl. Pyrolysis, 16 (1989) 323-333.

[14] J.M. Challinor, J. Anal. Appl. Pyrolysis, 20 (1991) 15-24. 
[15] J.W. de Leeuw and M. Baas, J. Anal. Appl. Pyrolysis, 26 (1993) 175-184.

[16] J.M. Challinor, J. Anal. Appl. Pyrolysis, 29 (1994) 223-224.

[17] D.J. Clifford, D.M. Carson, D.E. McKinney, J.M. Bortiatynski and P.G. Hatcher, Org. Geochem., 23 (1995) 169-175.

[18] W.C. Kossa, J. MacGee, S. Ramachandran and A.J. Webber, J. Chromatogr. Sci., 17 (1979) $177-$ 187.

[19] L.D. Metcalfe and C.N. Wang, J. Chromatogr. Sci., 19 (1981) 530-535.

[20] J.P. Dworzansky, L. Berwald and H.L.C. Meuzelaar, Appl. Environ. Microbiol., 56 (1990) $1717-1724$.

[21] J.P. Dworzansky, L. Berwald, W.H. MacClennen and H.L.C. Meuzelaar, J. Anal. Appl. Pyrolysis, 21 (1991) 221-232.

[22] J.M. Challinor, J. Anal. Appl. Pyrolysis, 18 (1991) 233-244.

[23] J.M. Challinor, J. Anal. Appl. Pyrolysis, 25 (1993) 349-360.

[24] K. Anderson and R. Winans, Anal. Chem., 63 (1991) 2901-2908.

[25] C. Saiz-Jimenez, B. Hermosin and J.J. OrtegaCalvo, Water Res., 27 (1993) 1693-1696.

[26] F. Martin, J.C. del Rio, F.J. González-Vila and T. Verdejo, J. Anal. Appl. Pyrolysis, 31 (1995) 7584.

[27] F. Martin, J.C. del Rio, F.J. González-Vila and T. Verdejo, J. Anal. Appl. Pyrolysis, 35 (1995) 113.

[28] J.C. del Rio, F.J. González-Vila, F. Martin and T. Verdejo, Org. Geochem. 22 (1994) 885-891.

[29] P.G. Hatcher, J.L. Faulon, D.A. Clifford and J.P. Mathews, in N. Senesi and T.M. Miano (Editors), Humic Substances in the Global Environment and Implications in the Human Health, Elsevier, Amsterdam, 1994, pp. 133-138

[30] P.G. Hatcher and D.J. Clifford, Org. Geochem., 21 (1994) 1081-1092.

[31] G. Chiavari, G. Torsi, D. Fabbri and G.C. Galletti, Analyst, 119 (1994) 1141-1150.

[32] J.C. del Rio, F. Martin, F.J. González-Vila and T. Verdejo, 13th International Mass Spectrometry Conference, Budapest, Book of Abstracts, 1994, p. 147.

[33] M.M. Mulder, E.R.E. van der Hage and J.J. Boon, Phytochem. Anal., 3 (1992) 165-172.

[34] C. Saiz-Jimenez, J.J. Ortega-Calvo and B. Hermosin, Naturwissenschaften, 81 (1994) 2829.

[35] P.G. Hatcher, 1995, personal communication.

[36] F. Martin and F.J. González-Vila, Z. Pflanzenernaehr. Bodenkd., 146 (1983) 653-659.
[37] G. Almendros, F. Martin, F.J. González-Vila and J.C. del Rio, J. Anal. Appl. Pyrolysis 25 (1993) 137-147.

[38] G. Holzer, T.F. Bourne and W. Berstch, J. Chromatogr., 468 (1988) 181-190.

[39] F. Martin, J.C. del Rio and F.J. González-Vila, unpublished results.

[40] F. Martin, C. Sáiz-Jiménez and F.J. GonzálezVila, Holzforschung, 33 (1979) 210-212.

[41] A.D. Pouwels and J.J. Boon, J. Wood Chem. Technol., 7 (1987) 197-213.

[42] O. Faix, D. Meier and I. Fortman, Holz Roh Werkst., 48 (1990) 281-285.

[43] J. Ralph and R.D. Hatfield, J. Agric. Food Chem., 39 (1991) 1426-1437.

[44] A.L. Bates, P.G. Hatcher, H.E. Lerch III, C.B. Cecil, S.G. Neuzil and Supardi, Org. Geochem., 17 (1991) 34-45.

[45] S.A. Stout, J.J. Boon and W. Spackman, Geochim. Cosmochim. Acta, 52 (1988) 405-414.

[46] J.M. Challinor, J. Anal. Appl. Pyrolysis, in press.

[47] M. Schnitzer and S.U. Khan, Humic Substances in the Environment, Marcel Dekker, New York, 1972.

[48] H.-R. Schulten, B. Plage and M. Schnitzer, Naturwissenschaften, 78 (1991) 311-312.

[49] H.-R. Schulten and M. Schnitzer, Naturwissenschaften, 80 ( 1993) 29-30.

[50] P.G. Hatcher, Org. Geochem., 16 (1990) 959968.

[51] P.G. Kralert, R. Alexander and R.I. Kagi, in D. Manning (Editor), Organic Geochemistry. Advances and Applications in the Energy and the Natural Environment, Manchester University Press, Manchester, 1991, pp. 634-636.

[52] J.C. del Rio, J. Garcia-Mollá, F.J. González-Vila and F. Martin, in K. фygard (Editor), Organic Geochemistry. Poster Sessions from the 16th International Meeting on Organic Geochemistry, Stavanger 1993, Falk Hurtigtrykk, Oslo, 1993. pp. 573-576.

[53] A.D. Barakat, Energy Fuels, 7 ( 1993) 988-993.

[54] K. Kawamura and R. Ishiwatari, Org. Geochem., 8 (1985) 197-201.

[55] K. Kawamura, E. Tannenbaum, B.J. Huizinga and I.R. Kaplan, Org. Geochem., 10 (1986) 1059 1065.

[56] S. Derenne, C. Largeau and E. Casadevall, Org. Geochem., 17 (1991) 597-602.

[57] B. Mycke and W. Michaelis, Org. Geochem., 10 (1986) 847-858.

J.C. del Rio, F. Martin and F.J. Gonzalez-Vila are at the Instituto de Recursos Naturales $y$ Agrobiologia de Sevilla, CSIC, P.O. Box 1052, 41080-Seville, Spain. 